\title{
ВОЛЬТ-АМПЕРНІ ХАРАКТЕРИСТИКИ, РЕЛАКСАЦЙНІ ВЛАСТИВОСТІ І ФОТОЧУТЛИВІСТЬ ПЛІВОК ПОЛІТІОПЕНТАЦЕНУ
}

\author{
М.П. ГОРІШНИй
}

\author{
УДК 537.311.322; 535,215 \\ Інститут фізики НАН України \\ (C) 2011 \\ (Просn. Науки, 46, Київ 03028; e-mail: gorishny@iop. kiev.ua)
}

Вперше спостерігали гістерезис темнових вольт-амперних характеристик (BАХ) плівок політіопентацену (ПТП), товщиною 1540 нм у сендвічних комірках ITO(ПТП)Ag при кімнатній температурі і напругах 0-10 В. Встановили, що при негативній полярності ІТО-електрода густина темнового струму $J$ зменшується до стаціонарного значення із сталими часу $\tau_{1}=10 \mathrm{c}$ i $\tau_{2}=150$ с. При позитивній полярності цього електрода після спаду $J$ з $\tau_{1}=10$ с спостерігається його зростання з $\tau_{2}=150$ с. Часові залежності $J$, густини струму короткого замикання $J_{\mathrm{sc}}$, фотоструму $J_{\mathrm{ph}}$ і алгебраїчної суми $J_{\mathrm{sc}}+J_{\mathrm{ph}}$ зумовлені релаксаційними змінами величини просторових приелектродних зарядів. Фоточутливість $S_{0}$ плівок ПТП при освітленні монохроматичним світлом 1,51 еВ (об'ємна фотогенерація) у п'ять разів більша від такої для світла 1,77 еВ (приелектродна фотогенерація). Приелектродна фотогенерація характеризується горизонтальною і лінійно зростаючою дільницями залежності $S_{0}(V)$, що зумовлені, відповідно, лінійною і квадратичною змінами $J_{\mathrm{sc}}+J_{\mathrm{ph}}$ від напруги $V$. Для об'ємної фотогенерації ця сума зв'язана із $V$ лінійною залежністю.

\section{1. Вступ}

Тіопохідні лінійних аценів вперше синтезовані Маршалком $[1,2]$. Науковий інтерес до вивчення властивостей халькогенопохідних лінійних аценів зумовлений порівняно малим для органічних матеріалів електричним опором $(\rho(300 \mathrm{~K})=100 \mathrm{Oм} \cdot \mathrm{M})$ тетратіотетрацену (ТТT), тетраселентетрацену (ТСТ) і гексатіопентацену (ГТП) [3, 4].

Спектри поглинання халькогенопохідних аценів зміщено у напрямку довгих хвиль (батохромний ефект) відносно таких для незаміщених молекул, що $\epsilon$ наслідком спряження валентних електронів гетероатомів халькогенів (S, Se i Te) із $\pi$-системами аценових кілець [5].

У реакції пентацену із сіркою утворюються ПТП суміш тіопохідних з різною кількістю атомів S. Найбільш ймовірними компонентами ПТП є тетратіопентацен (ТТП) і гексатіопентацен (ГТП), які можна ідентифікувати за піковими інтенсивностями і поло- женнями максимумів їх довгохвильових смуг поглинання [6].

В елементарній комірці кристалів ГТП знаходяться дві молекули. Трансляційно еквівалентні молекули об'єднуються у стоси із міжмолекулярною відстанню 0,354 нм. При цьому відстані S-S між сусідніми трансляційно нееквівалентними молекулами ще коротші і становлять 0,337-0,341 нм, тобто менші від ван-дерваальсових відстаней для атомів S (0,370 нм). Це свідчить про сильне перекривання орбіталей атомів $\mathrm{S}$, що сприяє міжмолекулярному перенесенню електричних зарядів як вздовж осей стосів, так і між стосами [7].

Фото-ерс (ФЕ) вільної поверхні плівок ПТП зумовлена протилежними за полярністю ФЕ Дембера $\left(V_{D}\right)$ і поверхнево-бар'єрною $\Phi \mathrm{E}\left(V_{b}\right)[6,8]$. Фотовольтаїчні властивості тонкоплівкових гетероструктур (ГС) на основі ГТП досліджено в [9].

У роботі [7] наведено характеристики транзисторів на основі плівок ГТП з рухливістю дірок $\mu_{p}=0,01$ $\mathrm{cm}^{2} \cdot \mathrm{B}^{-1} \cdot \mathrm{c}^{-1}$, великим відношенням $I_{1} / I_{2}=10^{7}$ струмів при увімкненому $\left(I_{1}\right)$ і вимкненому $\left(I_{2}\right)$ польовому електроді та малій пороговій напрузі цього електрода. Ці дослідження продовжено в [10], де повідомляється про можливість створення польових транзисторів 3 використанням кристалічних нанодротів $\left(\mu_{p}=0,27\right.$ $\left.\mathrm{cm}^{2} \cdot \mathrm{B}^{-1} \cdot \mathrm{c}^{-1}, I_{1} / I_{2}>10^{3}\right)$ і нанофібрил $\left(\mu_{p}=0,057\right.$ $\left.\mathrm{cm}^{2} \cdot \mathrm{B}^{-1} \cdot \mathrm{c}^{-1}, I_{1} / I_{2}=10^{4}\right)$ на основі ГТП. При цьому нанофібрили ГТП можуть формуватись на гнучких підкладках і використовуватись для виготовлення порівняно дешевих дисплеїв, інтегральних схем, сонячних комірок і елементів пам'яті. Одержані в [10] величини $\mu_{p}$ для кристалічних нанодротів ГТП є близькими до таких у польових транзисторах на основі плівок пентацену [11].

Таким чином, властивості пентацену та його тіопохідних нині інтенсивно досліджуються з метою їх використання як активних елементів польових транзисторів. Незважаючи на це, приелектродні процеси у плівках ГТП і ПТП, які можуть значно впливати на ефективність і стабільність електронних пристроїв 
на їх основі, вивчено недостатньо. Ці процеси є предметом досліджень нашої роботи.

\section{2. Методика експерименту}

Сендвічні комірки ITO(ПТП)Ag одержували послідовним термічним напиленням у вакуумі 0,67 мПа на кварцові підкладки із ІТО-електродом шару ПТП і верхнього металічного електрода. Конструкція цих комірок дозволяла контролювати величини опорів електродів. При вимірюванні ВАХ і залежностей темнового струму від часу ці комірки з'єднували із джерелом стабілізованої напруги типу П4105 і підсилювачем постійного струму У5-9 із цифровим вольтметром або самописцем на виході. Залежності від часу фотоструму $J_{\mathrm{ph}}$ i струму короткого замикання $J_{\mathrm{sc}}$ при модульованому освітленні досліджували підсилювачем змінного струму УПИ-1, який приєднували до електричного кола замість У5-9. Комірки освітлювали галогенною лампою розжарення через монохроматор SPM-2 або фільтри. Потужності падаючого на комірку постійного або модульованого світла вимірювали термостовпчиком РТН-20 або піроприймачем 3 чутливостями 0,83 і $250 \mathrm{~B} /$ Вт відповідно.

Як модулятор світла було використано алюмінієвий диск із симетричними секторними вирізами, при обертанні якого створювались прямокутні імпульси тривалістю 7 мс і фронтом наростання 20 мкс.

\section{3. Одержані експериментальні результати}

Темнові ВАХ сендвічних комірок ITO(ПТП)Ag наведено на рис. 1. Стрілками на них указано напрямки зміни прикладеної до електродів напруги $V$ (від нуля до деякого значення і навпаки). Позначимо густину струму і прикладену напругу при позитивній і негативній полярності ITО-електрода через $J_{+}, V_{+}$і $J_{-}$, $V_{-}$відповідно. Початкову ВАХ для $J_{+}$(крива 1 ) знімали при зростанні величини $V$ від 0 до 10 В. Після того змінювали полярність $V$ і ВАХ при зростанні $V$ від 0 до 10 В для $J_{-}$(крива 2) іде нижче від $J_{+}$(крива 1). Якщо $V_{-}$за модулем зменшували від 10 до $0 \mathrm{~B}$, то відповідна крива 3 проходить нижче від кривої 2. Після того змінювали полярність $V$ і знімали ВАХ для $J_{+}$при зростанні $V$ від 0 до 10 В (крива 4) і зменшенні $V$ від 10 до 0 В (крива 5). Отже, при циклічній зміні $V$ (криві 2-5) спостерігали гістерезис темнових ВАХ. Слід відзначити, що крива 4 іде нижче від кривої 1 , тобто сендвічна комірка ITO(ПТП) Ag не відновлює свої початкові характеристики. Після витримки цієї

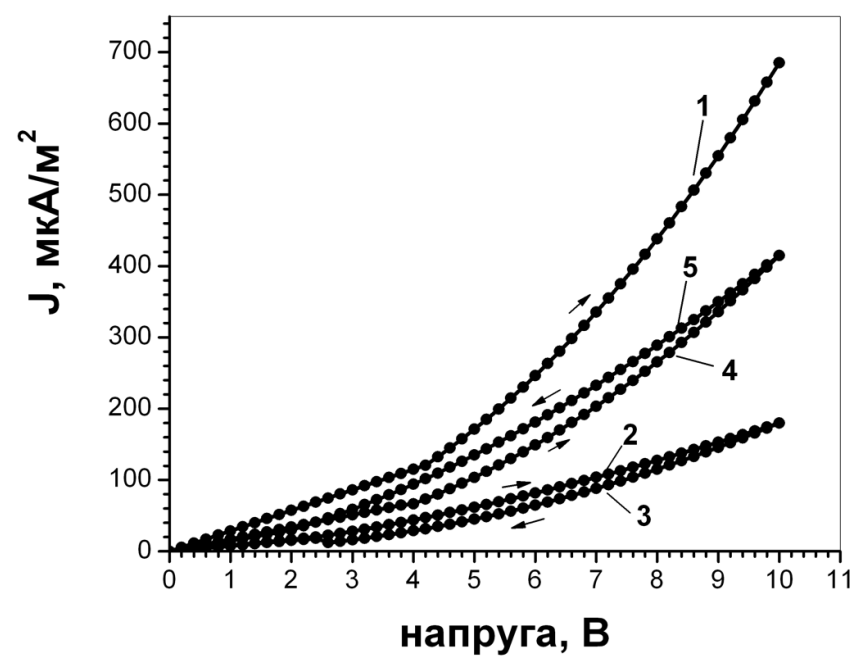

Рис. 1. Вольт-амперні характеристики темнового струму сендвічних комірок ITOПТПАg з плівками ПТП товщиною 1540 нм. Стрілки, напрямлені вправо і вліво, вказують на збільшення напруги від нульового до максимального значення (10 В) i її зменшення від максимального до нульового значення відповідно. При позитивній полярності ІТО-електрода записані лінї 1, 4 та 5 і негативній полярності цього електрода - лінії 2 і 3. Послідовність запису ВАХ визначається порядковим номером лінії

комірки в темноті протягом одного тижня процес запису BAX (криві 1-5) можна повторити.

У подвійному логарифмічному масштабі початкова BAX (крива 1) описується двома прямими лініями 3 різними кутовими коефіцієнтами $k$. При $0<V_{+} \leq 4$ $\mathrm{B} k_{1}=1,0$ (омічна дільниця) і $4<V_{+} \leq 10 \mathrm{~B} k_{2}=2,0$ (квадратична дільниця). Для кривої 2 величина напруги переходу від омічної до суперлінійної дільниці з $k_{2}=1,54$ знаходиться при $V_{-}=2,4$ В. Криві 3, 4 i 5 також складаються із двох дільниць, одна із яких $€$ омічною (при низьких $V$ ). Для них напруги переходу становлять 4,$6 ; 3,8$ і 2,0 B, $k_{2}$ дорівнюють 2,$00 ; 2,00$ i 1,62 відповідно.

Часові залежності $J(t)$ сендвічних комірок ITO(ПТП) Ag наведено на рис. 2. Величина $J_{-}$зменшується з часом при всіх $V_{-}$в діапазоні $0<V_{-} \leq 10$ В (рис. $2, b, d$ ). Ці кінетики складаються із швидкої i повільної компонент. У цьому діапазоні напруг спочатку спостерігається швидке зменшення $J_{+}$ до мінімального значення, а потім його повільне зростання до стаціонарної величини (рис. 2,a i 2,c). Аналітичні вирази для $J_{+}$і $J_{-}$складаються із алгебраїчної суми сталої складової $J_{0}$ і двох експонент:

$J=J_{0}+J_{1} e^{-\frac{t}{\tau_{1}}}+J_{2} e^{-\frac{t}{\tau_{2}}}$

де час $t$ вимірюється в секундах. 


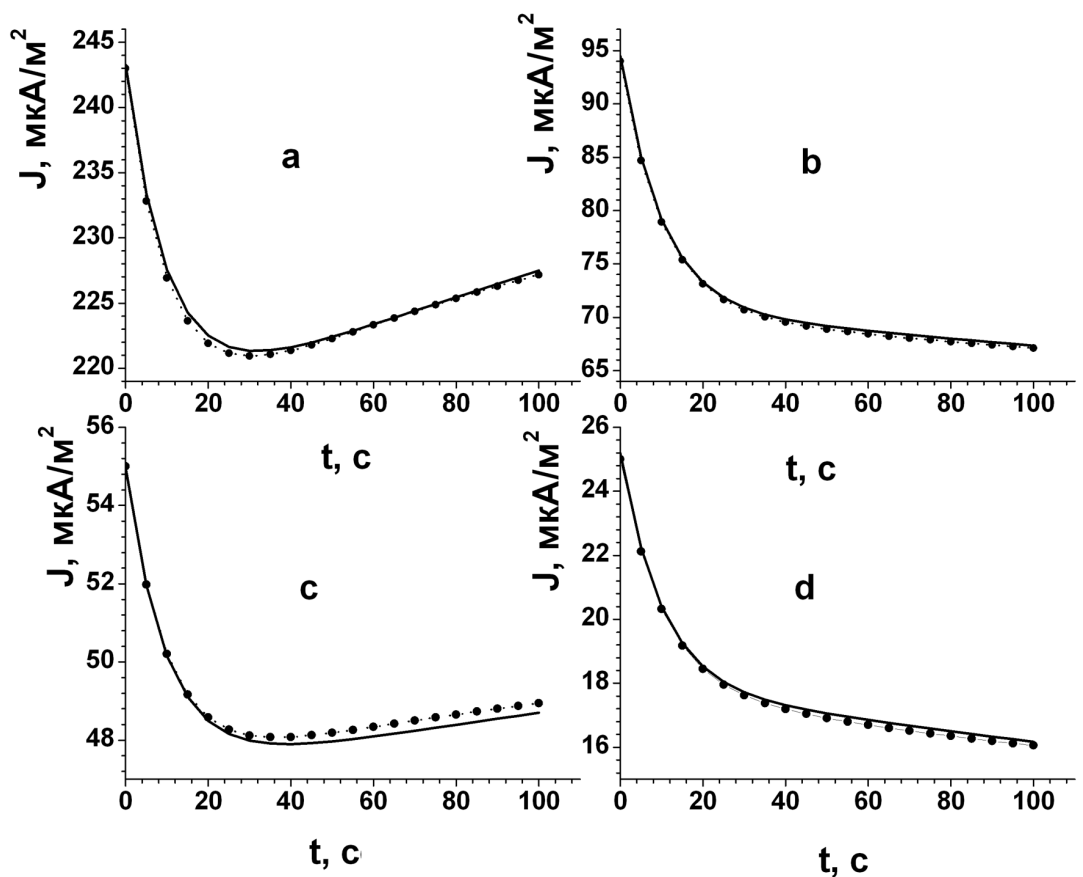

Рис. 2. Залежності темнового струму від часу сендвічних комірок ITОПТПАg при різних напругах. Експериментальні криві $J(t)$ наведено суцільними лініями із символами, а теоретичні - суцільними лініями. Потенціал на ITO-електроді становив: $+7,5$ В $(a) ;+3,0$ B $(c) ;-3,0$ B $(d)$ i $-7,5$ B $(b)$

Т а б л ц я 1. Значення величин $J_{0}, J_{1}, J_{2}, \Delta Q_{1}$ і $\Delta Q_{-}$

\begin{tabular}{|c|c|c|c|c|c|c|}
\hline $\begin{array}{c}\text { № } \\
\Pi / \Pi\end{array}$ & $\begin{array}{c}\text { Напруга на } \\
\text { ITО-електроді В }\end{array}$ & $\begin{array}{c}J_{0} \\
\mathrm{MKA} / \mathrm{M}^{2}\end{array}$ & $\begin{array}{c}J_{1} \\
\mathrm{MKA} / \mathrm{M}^{2}\end{array}$ & $\begin{array}{c}J_{2} \\
\mathrm{MKA} / \mathrm{M}^{2}\end{array}$ & $\begin{array}{c}\Delta Q_{1} \\
\text { мкКл/ } / \mathrm{m}^{2}\end{array}$ & $\begin{array}{c}\Delta Q_{-} \\
\text {мкКл/ }{ }^{2}\end{array}$ \\
\hline 1 & $+7,5$ & 240 & 28 & -25 & 280 & -3750 \\
\hline 2 & $-7,5$ & 63 & 23 & +8 & 230 & +1200 \\
\hline 3 & $+3,0$ & 51 & 8 & -4 & 80 & -600 \\
\hline 4 & $-3,0$ & 14 & 7 & +4 & 70 & +600 \\
\hline
\end{tabular}

Сталі часу $\tau_{1}$ i $\tau_{2}$ становлять 10 і 150 сек відповідно. Величини $J_{0}, J_{1}$ і $J_{2}$ наведено у табл. 1 .

Після вимкнення $V_{+}$або $V_{-}$в короткозамкнених комірках течуть струми розрядки, що протилежні за напрямками до $J_{+}$i $J_{-}$та зменшуються з часом до нуля. Початкові величини цих струмів залежать від значення вимкненої напруги і збільшуються із зростанням $V_{+}$або $V_{-}$.

Після виходу темнового струму $J$ на стаціонарне значення вмикали монохроматичне світло і вимірюва-

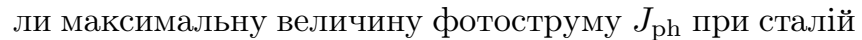
напрузі $V$. У випадку $J_{\mathrm{ph}}$ спостерігали тільки його повільне зменшення із сталою часу $\tau_{2}=150 \mathrm{c}$.

Модульоване монохроматичне світло з енергією фотонів $\left(E_{\phi}\right)$ 1,51 і 1,77 еВ використовували для вимірювання часових залежностей $J_{\mathrm{sc}}$ і алгебраїчної суми $J_{\mathrm{sc}}+J_{\mathrm{ph}}$ при вимкненій і увімкнутій напрузі відповідно.
В усіх випадках часові залежності описуються рівнянням

$X=A+B e^{-\frac{t}{\tau_{3}}}$,

де $X-J_{\mathrm{sc}}$ або $\left(J_{\mathrm{sc}}+J_{\mathrm{ph}}\right)$; А і В - стаціонарні значення і передекспоненціальні множники відповідно; $\tau_{3}=\tau_{2}=150 \mathrm{c}-$ сталі часу.

Величини коефіцієнтів $A$ і $B$ для $J_{\mathrm{sc}}$ i $J_{\mathrm{sc}}+J_{\mathrm{ph}}$ наведено в табл. 2 і 3 відповідно. У табл. 2 у першому рядку записано значення $\mathrm{A}$ і В для початкових $J_{\mathrm{sc}}$ $(V=0)$, а в рядках два - п'ять $-J_{\mathrm{sc}}$ після вимкнення негативного $(V<0)$ і позитивного $(V>0)$ потенціалу на ITO-електроді величиною 0,$17 ; 0,34 ; 0,68$ i 1,36 В відповідно. Знаки потенціалів на цьому електроді зберігаються і в табл. 3. Графіки часових залежностей $J_{\mathrm{sc}}$ i $J_{\mathrm{sc}}+J_{\mathrm{ph}}$ для монохроматичного світла з $E_{\phi}=1,77$ еВ (область сильного поглинання плівки ПТП) наведено на рис. $3, a, \sigma$. Для різних величин 
T а б и ц я 2. Значення $A$ i $B$ для $J_{\mathrm{sc}}$ після різних напруг $V$

\begin{tabular}{|c|c|c|c|c|c|c|c|c|}
\hline \multirow[t]{4}{*}{ Номер } & \multicolumn{8}{|c|}{$J_{\mathrm{sc}}, \mathrm{A} / \mathrm{M}^{2}$} \\
\hline & \multicolumn{4}{|c|}{$V \leq 0$} & \multicolumn{4}{|c|}{$V \geq 0$} \\
\hline & \multicolumn{2}{|c|}{$E_{\phi}=1,51 \mathrm{eB}$} & \multicolumn{2}{|c|}{$E_{\phi}=1,77 \mathrm{eB}$} & \multicolumn{2}{|c|}{$E_{\mathrm{\phi}}=1,51 \mathrm{eB}$} & \multicolumn{2}{|c|}{$E_{\phi}=1,77 \mathrm{eB}$} \\
\hline & $\begin{array}{c}A \\
\mathrm{MKA} / \mathrm{M}^{2}\end{array}$ & $\begin{array}{c}B \\
\mathrm{MKA} / \mathrm{M}^{2}\end{array}$ & $\begin{array}{c}A \\
\mathrm{MKA} / \mathrm{M}^{2}\end{array}$ & $\begin{array}{c}B \\
\mathrm{MKA} / \mathrm{M}^{2}\end{array}$ & $\begin{array}{c}A \\
\mathrm{MKA} / \mathrm{M}^{2}\end{array}$ & $\begin{array}{c}B \\
\mathrm{MKA} / \mathrm{M}^{2}\end{array}$ & $\begin{array}{c}A \\
\mathrm{MKA} / \mathrm{M}^{2}\end{array}$ & $\begin{array}{c}B \\
\mathrm{MKA} / \mathrm{M}^{2}\end{array}$ \\
\hline 1 & 2,00 & 0,00 & 2,59 & 0,00 & $-0,99$ & 0,00 & 1,80 & 0,00 \\
\hline 2 & 1,47 & $-3,39$ & 2,49 & $-0,13$ & 0,30 & 3,12 & 1,90 & 0,14 \\
\hline 3 & 0,58 & $-5,54$ & 2,40 & $-0,30$ & 1,44 & 4,69 & 2,12 & 0,24 \\
\hline 4 & $-0,50$ & $-13,75$ & 2,27 & $-0,57$ & 2,42 & 10,54 & 2,32 & 0,39 \\
\hline 5 & $-1,57$ & $-19,49$ & 1,85 & $-1,45$ & 5,70 & 19,52 & 2,54 & 1,17 \\
\hline
\end{tabular}

T а б л и ц я 3. Значення $A$ i $B$ для $J_{\text {sc }}+J_{\text {ph }}$ при різних напругах $V$

\begin{tabular}{|c|c|c|c|c|c|c|c|c|c|}
\hline \multirow[t]{4}{*}{ Номер } & \multirow[b]{4}{*}{$\begin{array}{l}V \\
B\end{array}$} & \multicolumn{8}{|c|}{$\left(J_{\mathrm{sc}}+J_{\mathrm{ph}}\right), \mathrm{MK} \mathrm{A} / \mathrm{m}^{2}$} \\
\hline & & \multicolumn{4}{|c|}{$V<0$} & \multicolumn{4}{|c|}{$V>0$} \\
\hline & & \multicolumn{2}{|c|}{$E_{\phi}=1,51 \mathrm{eB}$} & \multicolumn{2}{|c|}{$E_{\phi}=1,77 \mathrm{eB}$} & \multicolumn{2}{|c|}{$E_{\phi}=1,51 \mathrm{eB}$} & \multicolumn{2}{|c|}{$E_{\phi}=1,77 \mathrm{eB}$} \\
\hline & & $\begin{array}{c}A \\
\mathrm{MKA} / \mathrm{M}^{2}\end{array}$ & $\begin{array}{c}B \\
\mathrm{MKA} / \mathrm{M}^{2} \\
\end{array}$ & $\begin{array}{c}A \\
\mathrm{MKA} / \mathrm{M}^{2}\end{array}$ & $\begin{array}{c}B \\
\text { мKA } / \mathrm{M}^{2} \\
\end{array}$ & $\begin{array}{c}A \\
\mathrm{MKA} / \mathrm{M}^{2} \\
\end{array}$ & $\begin{array}{c}B \\
\mathrm{MKA} / \mathrm{M}^{2}\end{array}$ & $\begin{array}{c}A \\
\mathrm{MKA} / \mathrm{M}^{2} \\
\end{array}$ & $\begin{array}{c}B \\
\mathrm{MKA} / \mathrm{M}^{2} \\
\end{array}$ \\
\hline $1^{*}$ & 0,17 & 2,61 & 4,36 & 2,72 & 0,13 & $-0,99$ & $-1,86$ & 1,60 & $-0,13$ \\
\hline $2^{*}$ & 0,34 & 3,43 & 6,62 & 2,81 & 0,18 & $-1,42$ & $-3,55$ & 1,49 & $-0,49$ \\
\hline $3^{*}$ & 0,68 & 4,22 & 11,66 & 2,92 & 0,31 & $-1,99$ & $-7,97$ & 1,38 & $-0,69$ \\
\hline $4^{*}$ & 1,36 & 5,36 & 28,64 & 3,02 & 0,59 & $-2,85$ & $-16,93$ & 1,26 & $-0,96$ \\
\hline
\end{tabular}

$V_{+}\left(J_{\mathrm{sc}}+J_{\mathrm{ph}}\right)$ збільшується (рис. $3, a$, криві $\left.1^{*}-4^{*}\right) \mathrm{i}$ $J_{\text {sc }}$ зменшується (рис. $3, a$, криві $\left.1-5\right)$ з часом до стаціонарних значень. При цьому початкові і стаціонарні значення $J_{\mathrm{sc}}$ збільшуються, а відповідні значення $\left(J_{\mathrm{sc}}+J_{\mathrm{ph}}\right)$ зменшуються із зростанням величини $V_{+}$. Для різних $V_{-}\left(J_{\mathrm{sc}}+J_{\mathrm{ph}}\right)$ зменшується (рис. 3,6, криві $\left.1^{*}-4^{*}\right)$ і $J_{\mathrm{sc}}$ збільшується (рис. 3,6 , криві $\left.1-5\right)$ з часом до стаціонарних значень. При цьому початкові і стаціонарні значення $J_{\text {sc }}$ зменшуються, а відповідні значення $\left(J_{\mathrm{sc}}+J_{\mathrm{ph}}\right)$ збільшуються із зростанням величини $V_{-}$.

Для монохроматичного світла $3 E_{\phi}=1,51 \mathrm{eB}$ (область слабкого поглинання плівки ПТП) види часових кінетик $\left(J_{\mathrm{sc}}+J_{\mathrm{ph}}\right)$ і $J_{\mathrm{sc}}$ (рис. $\left.4, a, \sigma\right)$ такі самі, як і для світла з $E_{\phi}=1,77$ eВ (область сильного поглинання плівки ПТП). Відмінність полягає у тому, що при монохроматичному освітленні з $E_{\phi}=1,51 \mathrm{eB}$ $J_{\text {sc }}$ змінюється за напрямком (рис. 4, $а, 6$ криві 2-5) і відношення початкових до стаціонарних значень для $\left(J_{\mathrm{sc}}+J_{\mathrm{ph}}\right)$ і $J_{\mathrm{sc}}$ значно більші від таких для світла 3 $E_{\text {क }}=1,77 \mathrm{eB}$.

Фоточутливість плівок ПТП визначали за формулою

$S_{0}=\frac{J_{\mathrm{ph}}}{P \times V}$ де $J_{\mathrm{ph}}$ - густина фотоструму; $P$ - питома потужність $\left([\mathrm{P}]=\mathrm{B}_{\mathrm{T}} \cdot \mathrm{M}^{-2}\right)$ i $V$ - прикладена напруга.

Залежність $S_{0}$ і відношення $J_{\mathrm{ph}} / J$ від $V$ наведено на рис. 5. Суцільним лініям $\left(S_{0}\right)$ відповідає ліва, а штриховим $\left(J_{\mathrm{ph}} / J\right)$ - права вісь ординат. Для світла з $E_{\phi}=1,56 \mathrm{eB} S_{0}$ (область слабкого поглинання плівки ПТП) не залежить від $V_{+}$(пряма 2). При цьому $J_{\mathrm{ph}} / J$ зменшується зі зростанням $V$ (крива $\left.2^{*}\right)$. Якщо полярність IТО-електрода негативна, то $S_{0}$ і $J_{\mathrm{ph}} / J$ не залежать від величини $V_{-}$(прямі 1 і $1^{*}$ відповідно).

Для світла з $E_{\phi}=1,77 \mathrm{eB}$ (область сильного поглинання плівки ПТП) спостерігаються дві дільниці зміни $S_{0}$ і $J_{\mathrm{ph}} / J$. При $0<V \leq 1$ В ці характеристики не залежать від $V_{+}$(прямі 3 і $\left.3^{*}\right)$ і $V_{-}$(прямі 4 i $4^{*}$ відповідно). У діапазоні напруг $1<V \leq 4 \mathrm{~B} S_{0}$ збільшується із зростанням $V$ для обох полярностей ITOелектрода (прямі 3 і 4 відповідно). При цьому $J_{\mathrm{ph}} / J$ незначно зменшується (пряма 3* і збільшується (пряма $4^{*}$ ) із зростанням $V_{+}$і $V_{-}$відповідно. Порівняння величин $S_{0}$ показує, що плівки ПТП більш чутливі до світла $3 E_{\text {ф }}=1,51 \mathrm{eB}$.

\section{4. Обговорення одержаних експериментальних даних}

Структурні формули молекул ГТП і ТТП наведено в роботі [6]. Кістяк цих молекул утворюють п'ять 

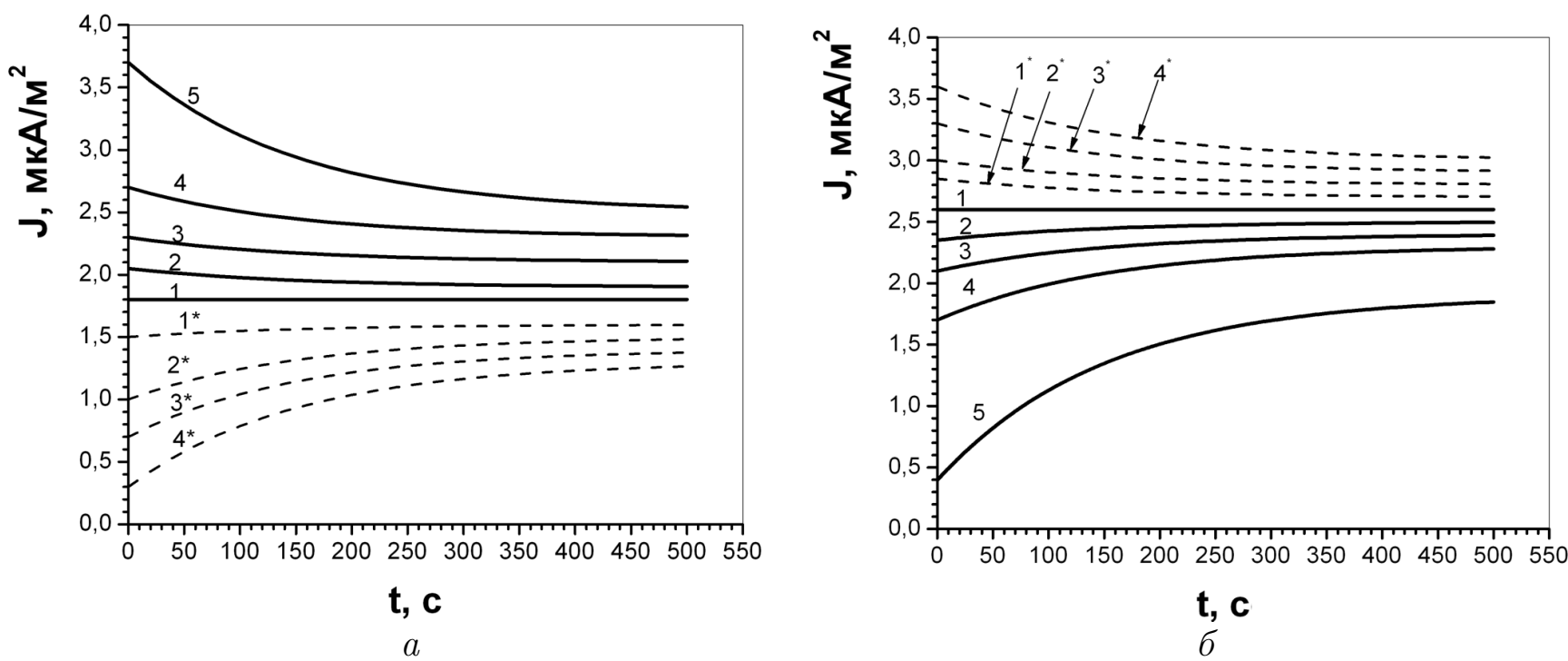

Рис. 3. Залежності від часу початкового струму короткого замикання $J_{\mathrm{sc}}$ (крива 1 ), $J_{\mathrm{sc}}$ після вимкнення напруги (криві 2-5) i $\left(J_{\mathrm{sc}}+J_{\mathrm{ph}}\right)$ при напругах 0,$17 ; 0,34 ; 0,68 \mathrm{i} 1,36 \mathrm{~B}$ (лінії $1^{*}-4^{*}$ відповідно) та модульованому 3 частотою 72 Гц освітленні 3 $E_{\phi}=1,77$ еВ. Полярність ІТО-електрода позитивна (a) і негативна (б)
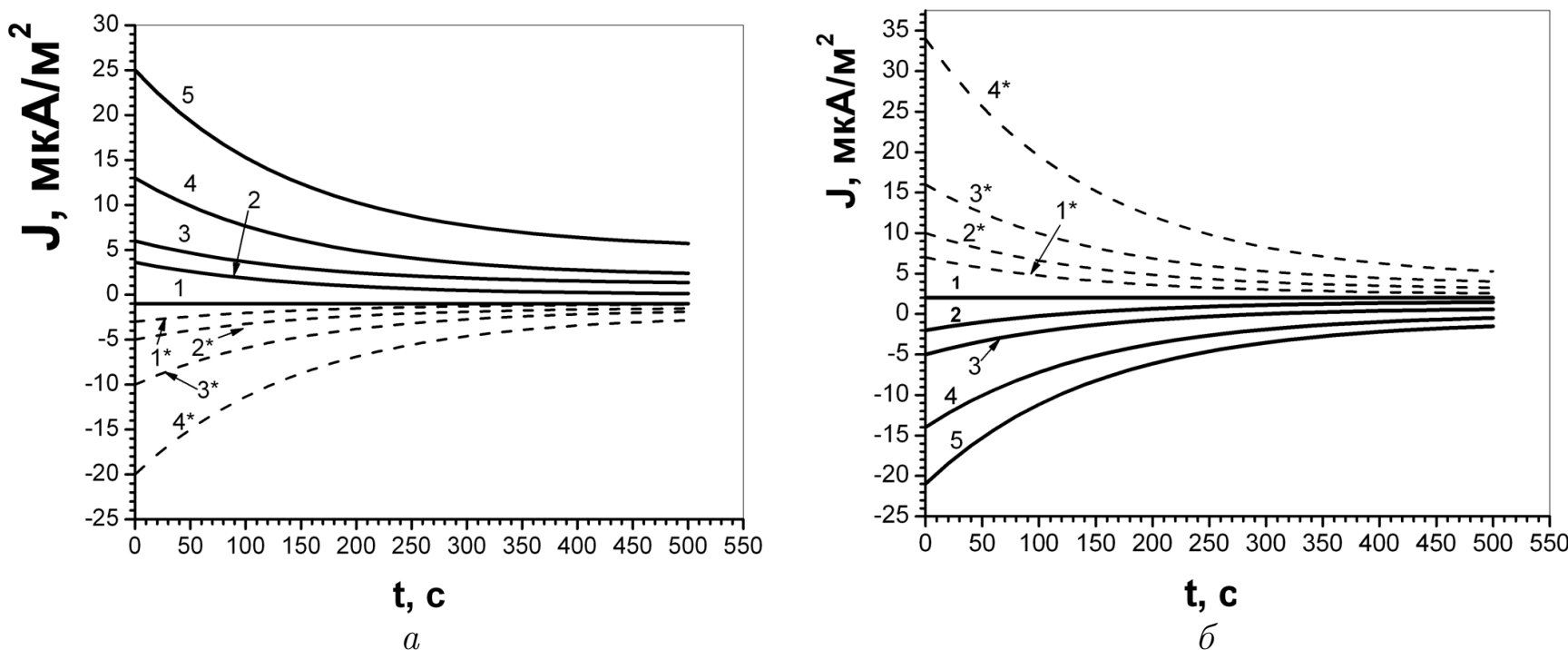

Рис. 4. Позначення кривих такі самі, як і на рис. 3. Модульоване освітлення з $E_{\phi}=1,51$ еВ: $a-$ полярність ITО-електрода позитивна; б - полярність ITО-електрода негативна

лінійно сполучених бензольних кілець, до якого у хімічно активних точках (вершинні атоми карбону (C) внутрішніх бензольних кілець) приєднані шість (ГТП) і чотири (ТТП) атоми сульфуру (S). Ідентифікацію ПТП, як суміші із молекул ГТП і ТТП, проводили за їх характерними смугами при 1,70 i 1,76 еВ відповідно [12]. Причиною появи цих смуг є приєднання зовнішніх електронів атомів $\mathrm{S}$ до $\pi$ системи пентаценового кістяка. Ці електрони знахо- дяться на $3 p_{z}$-орбіталях, які за розмірами значно переважають зовнішні $2 p_{z}$-орбіталі атомів $\mathrm{C}$ і легко поляризуються під дією електричних полів іонів. При цьому в молекулах ГТП і ТТП виникають наведені електричні диполі, які змінюють величину постійних електричних диполів C-S-зв'язків [13].

Припустимо, що робота виходу електрона $\phi$ для ПТП за величиною приблизно дорівнює такій для те- 
тратіотетрацену і становить 4,47 еВ [14]. Справедливість цього припущення підтверджується тим, що $\phi$ для цього класу сполук визначається валентними електронами атомів сульфуру. Робота виходу для ITO і $\mathrm{Ag}$ дорівнюють 5,15 і 4,30 еВ відповідно [15]. Встановлено [6, 8], що електропровідність ПТП діркова. Оскільки $\phi(\mathrm{ITO})>\phi(П Т П)>\phi(\mathrm{Ag})$, тоді у зонному наближенні вигин зон ПТП біля ITO- і Agелектродів для дірок антизапірний і запірний відповідно. При цьому у плівці ПТП біля ІTО формується позитивний, а біля $\mathrm{Ag}$ - негативний просторовий заряд. Наявність потенціального бар'єра для дірок біля Ag-електрода підтверджується асиметрією темнових BAX (рис. 1).

Оцінка величини питомого опору $\rho$ плівки ПТП на омічній дільниці ВАХ дає значення $10^{10}$ Ом·м, тобто ПТП є високоомним органічним напівпровідником. Дільниці $\mathrm{BAX} з k=2$ свідчать про те, що струм у плівках ПТП може обмежуватися об'ємним зарядом. Для підтвердження цього припущення необхідно виміряти ВАХ для плівок ПТП різних товщин і при $V>10 \mathrm{~B}$.

Швидка складова спадання $J(t)$ із сталою часу $\tau_{1}=10$ сек спостерігається при всіх $V$ і обох полярностях на IТО-електроді (рис. 2). Із таким же $\tau$ спадають струми розрядки. Такі зміни $J(t)$ свідчать про зміну величин просторових зарядів біля електродів. Величину цих змін $\Delta Q_{1}$ (табл. 1) оцінювали шляхом інтегрування швидкої складової $J(t)$ із сталою часу $\tau=10$ с. Вона залежить від напруженості зовнішнього електричного поля.

Характер повільної складової $J(t)$ з $\tau=150 \mathrm{c}$ визначається напрямком зовнішнього електричного поля. При накладанні позитивного потенціалу на ITO-електрод термічно генеровані у цьому електроді електронно-діркові пари розділяються зовнішнім електричним полем, і електрони переходять у зовнішню дільницю електричного кола, а дірки дрейфують до негативно зарядженого Ag-електрода. При цьому біля Ag-електрода електрони негативного просторового заряду $Q_{-}$, які знаходяться у зоні провідності ПТП, дрейфують до ІТО-електрода. У підсумку висота потенціального бар'єра для дірок знижується внаслідок зменшення величини $Q_{-}$із сталою часу $\tau=150 \mathrm{c}$. При цьому більша кількість дірок проникає у Agелектрод та нейтралізується електронами зовнішньої дільниці кола, що зумовлює зростання $J_{+}$з часом (рис. 2,a,c).

Негативно заряджений ITО-електрод інжектує у плівку ПТП електрони, які дрейфують до позитивно зарядженого Ag-електрода і збільшують величину

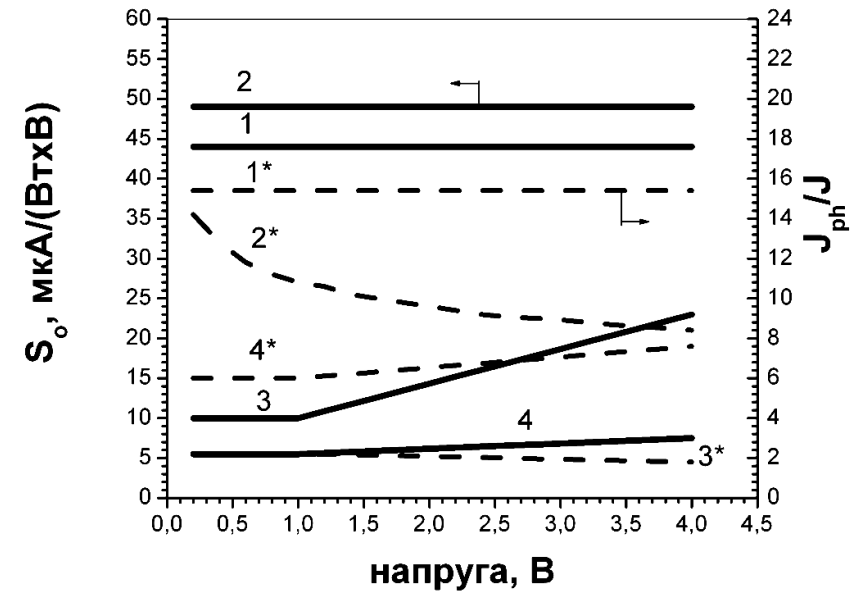

Рис. 5. Залежності фоточутливості $S_{0}$ (суцільні лінії, ліва вісь ординат) і відношення $J_{\mathrm{ph}} / J$ (штрихові лініі, права вісь ординат) від напруги при сталому за інтенсивністю освітленні 1,51 еВ (лінії 1, 1* і 2, 2* відповідно) і 1,77 еВ (лінії 3, 3* і 4, 4* відповідно)

$Q_{-}$із сталою часу $\tau=150$ с, що зумовлює кінетику повільного спаду $J_{-}$(рис. $\left.2, b, d\right)$. У цьому випадку дірки генеруються у Ag-електроді. Дірки з великою енергією долають потенціальний бар'єр і дрейфують у зовнішньому електричному полі до негативно зарядженого ITO-електрода та нейтралізуються електронами зовнішньої ділянки електричного кола. Розглянуті вище залежності $J(t)$ зумовлюють гістерезис темнових ВАХ (рис. 1). Величину зміни $\Delta Q_{-}$ біля Ag-електрода наведено у табл. 1. Ї̈̈ оцінювали шляхом інтегрування повільної складової залежності $J(t)$ із сталою часу $\tau=150 \mathrm{c}$.

При освітленні сандвіч-структур в об'ємі плівки ПТП і біля електродів можуть відбуватись такі процеси:

1. Фотогенерація електронно-діркових пар за рахунок поглинання електронами валентної зони фотонів з $E_{\phi}>E_{g}$, де $E_{g}-$ ширина забороненої зони.

2. Фотозбудження дірок у валентну зону. Цей процес еквівалентний переходу електрона із валентної зони на нейтральний або позитивно заряджений акцепторний рівень біля цієї зони.

3. Поява електронів у зоні провідності при їх фотозбудженні із донорних рівнів.

Нехай для ПТП $E_{g}=2,0$ еВ (величина порога власної фотопровідності ТТТ [16]). Тоді для пояснення фотопровідності плівок ПТП підходять процеси 2 і 3 , бо $E_{\phi}<E_{g}$.

Для оцінки ширини області фотогенерації $W$ носіїв заряду в плівці ПТП використовували закон 
Ламперта-Бера:

$I=I_{0} e^{-\alpha d}$,

де $I_{0}$ i $I$ - інтенсивності світла, що падає на плівку і проходить ї̈ відповідно; $\alpha$ - коефіцієнт поглинання; $d$ - товщина плівки ПТП.

Під $W$ будемо розуміти відстань між освітленою поверхнею і паралельною їй площиною, для якої коефіцієнт пропускання $T=I / I_{0}=0,1$. Підставимо значення $d=W$ і $T=0,1$ у (4). Після перетворень маємо

$W=\frac{2,3}{\alpha}$.

При $\alpha=6,7 \cdot 10^{4} \mathrm{~cm}^{-1}$ (сильне поглинання ПТП, $\left.E_{\phi}=1,77 \mathrm{eB}\right) W=373$ нм. Це значно менше від товщини плівки $d=1540$ нм і в цьому випадку область фотогенерації зосереджена біля ITО-електрода. Встановлено [8], що біля цього електрода $V_{D}<V_{b}$. Нерівноважні дірки дрейфують до поверхні ITO-електрода під дією приелектродного електричного поля і нейтралізуються електронами зовнішньої дільниці електричного кола. Крім того, біля ІТО-електрода в зоні провідності ПТП можуть з'являтися нерівноважні електрони внаслідок їх фотозбудження із донорних рівнів. Ці електрони дрейфують під дією приелектродного поля до Ag-електрода і переходять у зовнішню ділянку кола. Потоки нерівноважних носіїв заряду створюють $J_{\mathrm{sc}}$, величина якого визначається концентрацією цих носіїв заряду і ефективною напруженістю приелектродного електричного поля біля ITOелектрода.

Позитивне зміщення 0,17 В на ITО-електроді створює зовнішне електричне поле з напруженістю $E \approx$ $1 \cdot 10^{5} \mathrm{~B} / \mathrm{м}$, що зменшує $\dddot{11 ̈ ~ д л я ~ о б о х ~ п р и е л е к т р о д н и х ~}$ полів. При цьому алгебраїчна сума $J_{\mathrm{sc}}+J_{\mathrm{ph}}$ (рис. $3, a$, крива $1^{\prime}$ ) менша від $J_{s c 1}$ (рис. 3, $a$, пряма 1 ) на величину $J_{p h 1}$, яка зумовлена дрейфовим потоком нерівноважних дірок в об'єм плівки ПТП під дією зовнішнього електричного поля. Величина цієї суми збільшується з часом. Після встановлення стаціонарного значення $\left(J_{\mathrm{sc}}+J_{\mathrm{ph}}\right)<J_{s c 1}$ зовнішнє електричне поле вимикали і вимірювали $J_{s c 2}$ (рис. $3, a$, крива 2), яка більша від $J_{s c 1}$, тобто зразок не відновлює свої початкові характеристики. Для зовнішніх електричних полів з $E \geq 1 \cdot 10^{5} \mathrm{~B} /$ м збільшення $\left(J_{\mathrm{sc}}+J_{\mathrm{ph}}\right)$ (рис. $3, a$, криві $1^{\prime}-4^{\prime}$ ) і зменшення $J_{\text {sc }}$ (рис. $3, a$, криві 2-5) 3 часом до стаціонарних значень можна пояснити змінами величини позитивного просторового заряду $Q_{+}$ біля ITО-електроду. При позитивному зміщенні на
ІТО-електроді у приелектродній області виникають протилежно напрямлені дрейфові потоки нерівноважних дірок і електронів, що формують дві складові струму $\left(J_{\mathrm{sc}}\right.$ i $\left.J_{\mathrm{ph}}\right)$. Переважають потоки нерівноважних електронів в об'єм плівки ПТП і нерівноважних дірок до ІТО-електрода. Величина $Q_{+}$збільшується за рахунок нескомпенсованого заряду іонізованих донорів, що зумовлює збільшення вигину зон і $J_{\mathrm{sc}}$ відповідно. Рівноважне значення $J_{\mathrm{sc}}+J_{\mathrm{ph}}$ встановлюється при збільшеному $Q_{+}$. Стала часу цих процесів становить 150 с. В початковий момент після вимкнення зовнішнього електричного поля вигин зон достаньо великий, а товщина бар'єра мала. Це сприяє тунелюванню із ІТО-електрода в об'єм плівки ПТП фотогенерованих у цьому електроді електронів. Ці електрони захоплюються іонізованими донорами, що зумовлює зменшення із сталою часу 150 с величин $Q_{+}$i $J_{\mathrm{sc}}$.

При негативному зміщенні на ITО-електроді збільшуються вигини зон біля обох електродів. При цьому $J_{\mathrm{sc}}$ i $J_{\mathrm{ph}}$ співнапрямлені. Певна кількість електронів, інжектованих із ITО-електрода, захоплюється іонізованими електронними донорами, що зумовлює зменшення $Q_{+}$із сталою часу 150 с (рис. 3,6 , криві $1^{\prime}-$ $\left.4^{\prime}\right)$. Після вимкнення електричного поля $Q_{+}$збільшується за рахунок фотоіонізаціі донорів і дрейфу нерівноважних електронів до Аg-електрода (рис. 3,б, криві 1-5).

Для світла $3 E_{\phi}=1,51 \mathrm{eB}$, що слабко поглинається плівкою ПТП, $\alpha=1,5 \cdot 10^{4} \mathrm{~cm}^{-1} \mathrm{i} \mathrm{W}$ згідно із рівнянням (5) становить 1540 нм, тобто дорівнює товщині плівки ПТП. Це означає, що нерівноважні дірки i електрони фотогенеруються біля обох електродів і в об'ємі плівки ПТП. Великі початкові значення $J_{\mathrm{sc}}$ i $J_{\mathrm{ph}}$ порівняно із такими для світла з $E_{\text {ф }}=1,77 \mathrm{eB}$ зумовлені зростанням концентрації нерівноважних носіїв заряду завдяки об'ємній фотогенерації. Крім того, початкова величина $J_{\mathrm{sc}}$ змінює напрямок. Це зумовлено тим, що при освітленні через ITO-електрод результуюча $Ф Е$ формується протилежними за полярністю дифузійною $\left(V_{D}\right)$ і дрейфовою $\left(V_{b}\right)$ складовими $[6,8]$. Якщо $V_{D}>V_{b}$, то $J_{\mathrm{sc}}<0$ (рис. $4, a$, пряма 1), тобто переважає дифузійний потік нерівноважних дірок в об'єм плівки ПТП. При $V_{D}<V_{b} J_{\mathrm{sc}}>0$ (рис. 4,б, пряма 1) і більш інтенсивною стає дрейфова складова, що напрямлена до ІТО-електрода. Оскільки величини $V_{D}$ i $V_{b}$ суттєво не відрізняються за модулем, то коливання величини вигину зон біля електродів змінюють полярність результуючої ФЕ і, відповідно, напрямок початкового $J_{\mathrm{sc}}$. Залежності від часу $J_{\mathrm{sc}} \mathrm{i}$ $J_{\mathrm{sc}}+J_{\mathrm{ph}}$ для світла $3 E_{\mathrm{\phi}}=1,51 \mathrm{eB}$ (рис. $4, a$, б) опи- 
суються розглянутими вище механізмами для світла $3 E_{\phi}=1,77 \mathrm{eB}$.

Аналіз розглянутих вище часових залежностей $J$, $J_{\mathrm{sc}}, J_{\mathrm{ph}} \mathrm{i} J_{\mathrm{sc}}+J_{\mathrm{ph}}$ показує, що вони зумовлені змінами просторових зарядів біля електродів під дією зовнішнього електричного поля і освітлення. Можна припустити, що причиною цих змін є процеси взаємодії дірок та інжектованих електронів із відповідними пастками і рівнями прилипання у забороненій зоні ПТП. Крім того, свій внесок у ці процеси можуть вносити наведені зовнішнім електричним полем диполі в C-S-зв'язках молекул ТТП і ГТП. Встановлення природи цих механізмів буде предметом подальших досліджень.

Фоточутливості $S_{0}$ плівки ПТП при освітленні світлом, що слабко поглинається плівкою ПТП, для обох полярностей ITО-електрода близькі за величиною (рис. 5, прямі 1, 2) і в п'ять разів більші від таких для світла, що сильно поглинається плівкою ПТП (рис. 5, прямі 3 і 4). Це свідчить про те, що об'ємна фотогенерація нерівноважних носіїв заряду є більш ефективною порівняно із приелектродною фотогенерацією. При цьому для останньої характерні дві ділянки залежності $S_{0}(V)$, що зумовлені, відповідно, лінійною (горизонтальна ділянка $S_{0}$ ) і квадратичною (похила ділянка $S_{0}$ ) залежностями алгебраїчної суми $J_{\mathrm{sc}}$ i $J_{\mathrm{ph}}$ від прикладеної напруги. Для світла, що сильно поглинається плівкою ПТП, при $0<V<4$ В ця сума зв'язана із $V$ лінійно.

\section{5. Висновки}

Вперше спостерігали гістерезис темнових ВАХ плівок ПТП.

Залежності $J_{\mathrm{sc}}$ i $\left(J_{\mathrm{sc}}+J_{\mathrm{ph}}\right)$ від часу зумовлені зміною величини просторового заряду біля ITOелектрода при сильному поглинанні плівки ПТП $\left(E_{\mathrm{\phi}}=1,77 \mathrm{eB}\right)$ і просторових зарядів біля ITO- i Ag-електрода при слабкому поглинанні цієї плівки $\left(E_{\phi}=1,51 \mathrm{eB}\right)$ та співвідношенням величин $V_{D}$ і $V_{b}$.

Фоточутливість $S_{0}$ плівок ПТП при освітленні монохроматичним світлом 1,51 еВ (об'ємна фотогенерація) у п'ять разів більша від такої для світла 1,73 еВ (приелектродна фотогенерація).

Приелектродна фотогенерація характеризується горизонтальною і лінійно зростаючою дільницями залежності $S_{0}(V)$, що зумовлені, відповідно, лінійною і квадратичною залежностями алгебраїчної суми $J_{\text {sc }}$ i

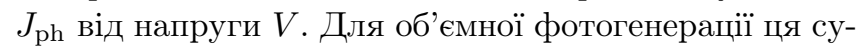
ма зв'язана із $V$ лінійно.
Роботу виконано в межах теми НАН України №1.4.B/134.

1. C. Marshalk, Bull. Soc. Chim. France 6, 1122 (1939).

2. C. Marshalk and C. Stumm, Bull. Soc. Chim. France 15, 418 (1948).

3. Y. Matsunaga, J. Chem. Phys. 42, 2248 (1965).

4. E.P. Goodings, D.A. Mitchard, and G. Owen, J. Chem. Phys. Trans. 1, 1310 (1972).

5. М.П. Горішний, УФЖ 47, 711 (2002).

6. М.П. Горішний, УФЖ 51, 339 (2006).

7. A.L. Briseno, Q. Miao, M.-M. Ling, C. Reese, H. Meng, Zh. Bao and F. Wudl, J. Am. Chem. Soc., 128, 15576 (2006).

8. М.П. Горішний, УФЖ 52, 1154 (2007).

9. P. Lutsyk and Ya. Vertsimakha, Mol. Cryst. Liquid Cryst. 426, 253 (2005).

10. A.L. Briseno, S.C.B. Mannsfeld X. Lu, Y. Xiong, S.A. Jenekhe, Zh. Bao, and Y. Xia, Nano Lett. 7, 668 (2007).

11. V.D. Park, J.Ah. Lim, H.S. Lee and K. Cho, Materialstoday 10, 46 (2007).

12. М.П. Горишный, М.В. Курик, Л. Либера, УФЖ 32, 1013 (1987).

13. М.П. Горишный, П.А. Кондратенко, УФЖ 34, 839 (1989).

14. Э.А. Силиньш, Электронные состояния органических молекулярных кристаллов (Зинатне, Рига, 1978).

15. В.С. Фоменко, Эмиссионные свойства материалов (Наукова думка, Киев, 1981).

16. Э.А. Силиньш, М.В. Курик, В. Чапек, Электронные прочессы в органических молекулярных кристаллах (под ред. Э.А. Силиньша, Зинатне, Рига, 1988).

Одержано 03.03.11

ВОЛЬТ-АМПЕРНЫЕ ХАРАКТЕРИСТИКИ,

РЕЛАКСАЦИОННЫЕ СВОЙСТВА

И ФОТОЧУВСТВИТЕЛЬНОСТЬ

ПЛЕНОК ПОЛИТИОПЕНТАЦЕНА

М.П. Горишный

Р е $з$ ю м е

Впервые наблюдали гистерезис темновых вольт-амперных характеристик (BAX) пленок политиопентацена (ПТП) толщиной 1540 нм в сэндвичных ячейках $\mathrm{ITO}(П Т П) \mathrm{Ag}$ при комнатной температуре и напряжениях 0-10 В. Установили, что при отрицательной полярности ITО-электрода плотность темнового тока $J$ уменьшается до стационарного значения с постоянными времени $\tau_{1}=10$ с и $\tau_{2}=150$ с. При положительной полярности этого электрода после спада $J$ с $\tau_{1}=10$ с наблюдается его возрастание с $\tau_{2}=150$ с. Часовые зависимости $J$, 
плотности тока короткого замыкания $J_{\mathrm{sc}}$, фототока $J_{\mathrm{ph}}$, и алгебраической суммы $J_{\mathrm{sc}}+J_{\mathrm{ph}}$ обусловлены релаксационными изменениями величины пространственных приэлектродных зарядов. Фоточувствительность $S_{0}$ пленок ПТП при освещении монохроматическим светом 1,51 эВ (объемная фотогенерация) в пять раз превышает таковую для света 1,77 эВ (приэлектродная фотогенерация). Приэлектродная фотогенерация характеризуется горизонтальным и линейно возрастающим участками зависимости $S_{0}(\mathrm{~V})$, которые обусловлены, соответственно, линейным и квадратическим изменениями $J_{\mathrm{sc}}+J_{\mathrm{ph}}$ от напряжения $V$. Для объемной фотогенерации эта сумма связана с $V$ линейной зависимостью.

\section{CURRENT-VOLTAGE CHARACTERISTICS, RELAXATION PROPERTIES, AND PHOTOSENSITIVITY OF POLYTHIOPENTACENE FILMS}

\section{M.P. Gorishnyi}

Institute of Physics, Nat. Acad. of Sci. of Ukraine (46, Nauky Prosp., Kyiv 03680, Ukraine; e-mail: gorishny@iop.kiev.ua)

$\mathrm{S} u \mathrm{~mm}$ a r y

The hysteresis of dark current-voltage characteristics (JVC) has been observed for the first time for polythiopentacene (PTP) films
$1540 \mathrm{~nm}$ in thickness in sandwich-like ITO(PTP)Ag cells at room temperature and in the range of applied voltages $V$ from 0 to $10 \mathrm{~V}$. At the negative polarity of the ITO electrode, the dark current density $J$ was found to diminish to a stationary value with the time constants $\tau_{1}=10 \mathrm{~s}$ and $\tau_{2}=150 \mathrm{~s}$. If the polarity of this electrode was positive, the current-density reduction with $\tau_{1}=10 \mathrm{~s}$ was followed by the current-density increase with $\tau_{2}=150 \mathrm{~s}$. The time dependences of $J$, the densities of the short circuit current, $J_{\mathrm{sc}}$, and photocurrent, $J_{\mathrm{ph}}$, and, hence, the algebraic sum $J_{\mathrm{sc}}+J_{\mathrm{ph}}$ were found to be governed by relaxation changes in the magnitudes of near-electrode space charges. The photosensitivity $S_{0}$ of PTP films at their illumination with monochromatic light with a quantum energy of $1.51 \mathrm{eV}$ (photogeneration in the bulk) turned out five times as high as that, when the light quantum energy was $1.77 \mathrm{eV}$ (photogeneration near the electrode). The near-electrode photogeneration is characterized by the presence of horizontal and linearly increasing sections in the dependence $S_{0}(V)$, which are associated with linear and quadratic, respectively, variations of the sum $J_{\mathrm{sc}}+J_{\mathrm{ph}}$ with the changing voltage $V$. For photogeneration in the bulk, this sum depends linearly on $V$. 